\title{
PENGARUH PENENTUAN JUMLAH PEMESANAN PADA BULLWHIP EFFECT
}

\author{
Puji Lestari, Liong Irena, I Gede Agus Widyadana \\ Program Studi Teknik Industri, Universitas Kristen Petra \\ Siwalankerto, Surabaya, Indonesia
}

(Received: August 14, 2016 / Accepted: February 28, 2017)

\begin{abstract}
Abstrak
Bullwhip effect adalah suatu kondisi dimana terjadi peningkatan variasi permintaan dalam suatu rantai pasok. Bullwhip effect ini dapat diakibatkan oleh beberapa faktor salah satunya yaitu jumlah pemesanan. Jumlah pemesanan yang dilakukan oleh masing-masing pemasok akan mempengaruhi jumlah pemesanan pada pemasok yang lain. Perbedaan jumlah pemesanan antar pemasok ini akan menimbulkan bullwhip effect. Penelitian ini akan menunjukkan pengaruh penentuan jumlah pemesanan terhadap bullwhip effect dengan menggunakan metode Silver Meal dan Lot For Lot. Hasil yang diperoleh diukur dengan melihat perbedaan biaya per unit pada keseluruhan rantai pasok. Hasil penelitian menunjukkan bahwa pihak pembeli lebih baik menggunakan metode Silver Meal karena variasi permintaan masih mewakili permintaan yang sebenarnya sedangkan pada pihak penjual lebih baik menggunakan Lot For Lot karena variasi permintaan sudah tidak dapat mewakili permintaan sebenarnya. Penggunaan metode Lot For Lot pada pihak penjual menyebabkan variasi permintaan yang sudah tidak mewakili permintaan sebenarnya tidak diperhitungkan.
\end{abstract}

Kata kunci: biaya per unit; bullwhip effect; lot sizing

\begin{abstract}
Bullwhip effect is the increased variability of demand in supply chain. Order quantity could be a factor that cause bullwhip effect. Deciding order quantity by an actor in supply chain will affect the order quantity by the other actors. Different order quantity is known as bullwhip effect. This research will show the effect of lot sizing, Silver Meal and Lot For Lot, on bullwhip effect. The result could be seen on the cost per unit in supply chain. The result shows that Silver Meal is better used by a buyer because demand variation could present the real demand, while Lot For Lot is better used by a seller because demand variation could not present the real demand. Using Lot For Lot causes the demand variation is not included.
\end{abstract}

Keywords: cost per unit; bullwhip effect; lot sizing

\section{Pendahuluan}

Bullwhip effect adalah peristiwa terdistorsinya informasi yang terjadi dalam rantai pasok. Informasi yang yang terdistori berupa jumlah pemesanan dan permintaan dari level pembeli sampai dengan level penjual. Bullwhip effect ini dapat dipengaruhi oleh banyak faktor diantarnya yaitu perubahan harga, jumlah pemesanan, dan peramalan permintaan. Bullwhip effect yang timbul dalam rantai pasok dapat memberikan dampak yang besar dalam hal biaya seperti biaya pemesanan dan biaya penyimpanan. Salah satu cara yang dapat dilakukan untuk meminimalkan bullwhip effect adalah dengan saling

\footnotetext{
*) Penulis Korespondensi. email:
}

menukar informasi antar pemasok. Namun cara ini biasanya tidak dilakukan oleh pemasok dikarenakan setiap pemasok tidak ingin pemasok lain mengetahui informasi internal yang ada. Cara lain yang dapat dilakukan yaitu dengan mengendalikan jumlah pemesanan dengan menggunakan metode lot sizing.

Penentuan jumlah pemesanan dapat dilakukan dengan beberapa metode, seperti Silver Meal, Lot For Lot, part periode balancing, dan least unit cost. Secara umum, penentuan jumlah pemesanan hanya memperhitungkan jumlah pemesanan pada satu pihak. Penelitian ini merupakan pengembangan dari penelitian yang dilakukan oleh Pujawan (2003), yaitu penentuan jumlah pemesanan pada dua pihak dalam rantai pasok, dalam hal ini adalah pembeli dan penjual. Penelitian ini menggunakan metode Silver Meal dan Lot For Lot dalam penentuan jumlah 
pemesanan. Metode Silver Meal digunakan dengan memperhitungkan periode pemesanan yang berdasarkan rata-rata biaya periode sedangkan metode Lot For Lot digunakan dengan kondisi pemesanan dilakukan setiap periode untuk meminimalkan biaya penyimpanan. Namun pada penelitian ini akan melihat biaya secara keseluruhan dua perussahaan (pembeli dan penjual).

\section{Kajian Literatur}

Bullwhip merupakan fenomena dimana perintah yang diterima oleh pemasok cenderung memiliki varians lebih besar dari penjualan kepada pembeli ${ }^{1}$. Hal ini dikarenakan kesalahan dari interpretasi data permintaan di tiap - tiap rantai distribusi dan sistem informasi di dalam pendistribusiannya tersebut bersifat dua arah dimana pembeli menyampaikan informasi permintaan dari konsumen ke distributor dan dari distributor lalu menyampaikan informasi ke manufaktur dan sebaliknya ${ }^{2}$.

Salah satu penyebab dari bullwhip effect adalah penentuan jumlah pemesanan. Penentuan jumlah pemesanan adalah suatu cara yang dilakukan oleh perusahaan dalam melakukan pemesanan untuk mengetahui jumlah barang yang sebaiknya dipesan. Kebanyakan perusahaan tidak memiliki sistem pemesanan yang pasti sehingga variabilitas pemesanan akan lebih besar daripada variabilitas permintaan. Hal ini juga dipengaruhi oleh adanya biaya transportasi, dimana biaya transportasi akan lebih murah jika pemesanan dilakukan dalam jumlah besar sehingga perusahaan akan cenderung melakukan pemesanan dalam jumlah banyak.

Perencanaan persediaan adalah teknik yang digunakan untuk menentukan jumlah barang yang harus disediakan. Perencanaan persediaan dapat dilakukan dengan cara peramalan atau dengan menentukan jumlah pemesanan persediaan. Peramalan adalah ilmu yang digunakan untuk memperkirakan keadaan di masa yang akan datang dengan memproyeksi data masa lampau ke masa yang akan datang dengan model matematika ${ }^{3}$. Sedangkan lot sizing adalah suatu ukuran atau jumlah pemesanan dimana pemesanan yang telah ada harus tersedia di awal periode produksi ${ }^{4}$.

Penentuan jumlah pemesanan dapat dilakukan dengan dua pendekatan yaitu secara periode ataupun secara level. Pendekatan yang sering digunakan yaitu pendekatan secara level dimana banyak digunakan pada Material Requirement Planning (MRP). Penelitian ini akan difokuskan dalam penerapan metode Silver Meal dan Lot For Lot. Hal didasarkan pada karakteristik yang dimiliki oleh kedua metode ini.

Silver Meal merupakan salah satu teknik dalam penentuan jumlah pemesanan yang digunakan untuk meminimalkan total biaya per periode. Metode Silver Meal ini digunakan dengan menentukan jumlah periode yang dapat dipenuhi untuk setiap kali pemesanan. Pemesanan dilakukan untuk memenuhi permintaan dari beberapa periode. Kuantitas barang yang dipesan dapat ditentukan dengan menggunakan Persamaan $1^{5}$.

$Q_{t}=d_{t}+(m-1) \mu-I_{t-1}$, jika $d_{t}-I_{t-1}>0$

$Q_{t}=0$, jika $d_{t}-I_{t-1} \leq 0$

Dimana:

$Q_{t}=$ Kuantias pemesanan

$d_{t}=$ Permintaan pada periode $t$

$m=$ Jumlah periode yang dipenuhi

$\mu=$ Rata-rata permintaan

$I_{t-1}=$ Jumlah barang yang disimpan pada periode $t-1$

Jumlah pemesanan pada periode $t \quad\left(Q_{t}\right)$ digunakan untuk memenuhi permintaan selama $m$ periode. Besarnya permintaan pada periode $t\left(d_{t}\right)$ telah diketahui secara pasti dan jumlah barang yang disimpan di akhir periode $t$ adalah $I_{t}$.

Metode Lot For Lot merupakan metode yang paling sederhana dimana ukuran disesuaikan dengan jumlah pesanan pada satu periode tunggal. Konsep Lot For Lot ini bertujuan untuk meminimalkan biaya penyimpanan, sehingga biaya simpan dengan metode ini sama dengan nol. Dengan demikian, pemesanan akan dilakukan setiap periode untuk memenuhi periode pada saat itu. Secara umum, penggunaan metode ini digunakan untuk item-item yang mempunyai biaya penyimpanan yang tinggi. Kuantitas barang yang dipesan dengan menggunakan metode Lot For Lot dapat dilihat pada Persamaan 2.

$Q_{t}=d_{t}$

\section{Model Material Requirement Planning Penjual- Pembeli}

Penentuan kuantitas pemesanan yang baik dapat mengurangi bullwhip effect. Penentuan kuantitas pemesanan ini dapat dilakukan dengan menggunakan beberapa metode. Metode yang digunakan dalam penentuan jumlah pemesanan dalam penelitian ini adalah metode Silver Meal dan metode Lot For Lot. Simulasi dilakukan hanya pada dua rantai dalam rantai pasok, yaitu pembeli dan penjual. Simulasi ini direplikasi sebanyak sepuluh kali.

Permintaan dari konsumen diasumsikan berdistribusi normal dengan rata-rata $\mu$ dan standar deviasi $\sigma$. Simulasi dilakukan untuk tiga tahun (156 minggu). Data permintaan mingguan diperoleh dengan membangkitkan bilangan acak pada Microsoft Excel yang berdistribusi normal dengan rata-rata 200 dan standar deviasi 20. Biaya penyimpanan yang dikenakan untuk setiap minggu adalah sebesar 1 sedangkan biaya yang dikeluarkan untuk satu kali pemesanan adalah sebesar 400. Lead time pada penelitian ini diasumsikan nol. Asumsi lain yang digunakan adalah jenis barang hanya terdiri dari satu tipe barang. Data yang digunakan ini merupakan data dari studi literatur Pujawan (2003).

Nilai $m$ pada metode Silver Meal adalah jumlah periode dimana jumlah permintaannya ingin dipenuhi 
dalam satu kali pemesanan. Jumlah periode ditentukan dengan melihat rata-rata biaya minimum per periode. Rata-rata biaya minimum untuk setiap periode dihitung sampai biaya pada periode $n$ lebih besar daripada periode $n-1$. Contoh perhitungan nilai $m$ dapat dilihat pada Gambar 1 .

$$
\begin{aligned}
& C_{1}=A=400 \\
& C_{2}=\frac{A+\left(h \times D_{2}\right)}{2}=\frac{400+(1 \times 225)}{2}=312.5 \\
& C_{3}=\frac{A+\left(h \times D_{2}\right)+\left(2 \times h \times D_{3}\right)}{2}=\frac{400+(1 \times 225)+(2 \times 1 \times 238)}{3}=367
\end{aligned}
$$

Gambar 1. Perhitungan Nilai $m$

Gambar 1 menunjukkan bahwa rata-rata biaya yang dikeluarkan apabila hanya melakukan pemesanan untuk memenuhi permintaan satu minggu saja sama dengan biaya pemesanan, yaitu 400. Ratarata biaya apabila memenuhi permintaan dua minggu dalam satu kali pemesanan dikenakan biaya simpan selama satu minggu. Jumlah permintaan minggu kedua dalam perhitungan ini adalah sebanyak 225 unit, sehingga diperoleh rata-rata biaya sebesar 312.5. Gambar 1 menunjukkan rata-rata biaya minimum yang dikeluarkan untuk memenuhi permintaan selama tiga minggu adalah sebesar 367 dengan mempertimbangkan biaya simpan selama dua minggu. Biaya ini lebih besar daripada biaya untuk memenuhi permintaan dua minggu, sehingga perhitungan untuk nilai $m$ dihentikan. Jadi, perhitungan Silver Meal dilakukan untuk memenuhi permintaan selama dua minggu $(\mathrm{m}=2)$.

Tabel 1. Contoh Perhitungan Silver Meal Tanpa Safety Stock

\begin{tabular}{|c|c|c|c|c|c|c|c|c|}
\hline \multicolumn{7}{|c|}{ Retailer } \\
\hline Ilinggu Ke & Demand & Q & Inventory Demand-Inrentor & A & Holding Cost & Total Cost \\
\hline 0 & & & 0 & & & & \\
\hline 1 & 225 & 425 & 200 & 225 & 400 & 200 & 600 \\
\hline 2 & 238 & 238 & 200 & 38 & 400 & 200 & 600 \\
\hline 3 & 201 & 201 & 200 & 1 & 400 & 200 & 600 \\
\hline 4 & 217 & 217 & 200 & 17 & 400 & 200 & 600 \\
\hline 5 & 215 & 215 & 200 & 15 & 400 & 200 & 600 \\
\hline 6 & 182 & 0 & 18 & .18 & 0 & 18 & 18 \\
\hline 7 & 189 & 371 & 200 & 171 & 400 & 200 & 600 \\
\hline 8 & 196 & 0 & 4 & .4 & 0 & 4 & 4 \\
\hline
\end{tabular}

yang menunjukkan pemesanan dilakukan setiap dua minggu sekali. Perbedaan ini menyebabkan adanya penggunaan safety stock dalam perhitungan Silver Meal sehingga pemesanan akan tetap dilakukan setiap dua minggu sekali. Perhitungan nilai safety stock dapat dilihat pada Gambar 2.

$$
\begin{aligned}
& \text { Safety stock }=Z \times \sigma \times \sqrt{m+L} \\
& \text { Safety stock }=1.96 \times 20 \times \sqrt{2+0} \\
& \text { Safety stock }=55 \text { unit }
\end{aligned}
$$

\section{Gambar 2. Perhitungan Safety Stock}

Nilai safety stock yang diperoleh dari hasil perhitungan (Simchi-Levi dan Kaminsky, 2003) adalah sebanyak 55 unit. Nilai $z$ yang digunakan dalam penentuan jumlah safety stock adalah 1.96. Jumlah pemesanan digunakan untuk memenuhi permintaan 2 minggu atau dengan kata lain, nilai $m$ yang digunakan adalah 2 sedangkan lead time diasumsikan nol.

Tabel 2. Contoh Perhitungan Silver Meal pada Level Pembeli

\begin{tabular}{|c|c|c|c|c|c|c|c|}
\hline \multicolumn{7}{|c|}{ Pembeli } \\
\hline Mlinggu Ke & Demand & Q & Inventory & Demand-Iwentory & 1 & Holding Cost & Iotal Cost \\
\hline 0 & & & 0 & & & & \\
\hline 1 & 225 & 480 & 255 & 225 & 400 & 255 & 655 \\
\hline 2 & 238 & 0 & 17 & .17 & 0 & 17 & 17 \\
\hline 3 & 201 & 439 & 255 & 184 & 400 & 255 & 655 \\
\hline 4 & 217 & 0 & 38 & .38 & 0 & 38 & 38 \\
\hline 5 & 215 & 432 & 255 & 177 & 400 & 255 & 655 \\
\hline
\end{tabular}

Tabel 2 merupakan perhitungan dalam menentukan jumlah pemesanan yang dilakukan dengan metode Silver Meal. Permintaan pada minggu pertama adalah sebanyak 225. Jumlah barang yang disimpan pada periode sebelumnya adalah nol sehingga diperoleh jumlah pemesanan untuk minggu pertama sebanyak 480 unit. Kuantitas pemesanan untuk minggu pertama adalah 480 unit. Perhitungan ini dilakukan hingga diperoleh kuantitas pemesanan untuk 156 minggu. Jumlah pemesanan pada level pembeli ini akan menjadi jumlah pemintaan pada level penjual.

Tabel 1 adalah perhitungan dengan metode Silver Meal tanpa mempertimbangkan safety stock. Hasil menunjukkan bahwa pemesanan dilakukan disetiap minggu. Hal ini berbeda dari hasil penentuan nilai $m$ 
Tabel 3. Contoh Perhitungan Silver Meal pada Level Penjual

\begin{tabular}{|c|c|c|c|c|c|c|c|}
\hline \multicolumn{7}{|c|}{ Penjual } \\
\hline Clingu Ke & Demand & Q & Imventory & Demand-Iwrentory & 1 & Holding Cost & Total Cost \\
\hline 0 & & & 0 & & & & \\
\hline 1 & 480 & 735 & 255 & 480 & 400 & 255 & 655 \\
\hline 2 & 0 & 0 & 255 & .255 & 0 & 255 & 255 \\
\hline 3 & 439 & 439 & 255 & 184 & 400 & 255 & 655 \\
\hline 4 & 0 & 0 & 255 & .255 & 0 & 255 & 255 \\
\hline 5 & 432 & 432 & 255 & 177 & 400 & 255 & 655 \\
\hline
\end{tabular}

Tabel 3 merupakan hasil perhitungan Silver Meal pada level penjual. Jumlah permintaan diperoleh dari jumlah pemesanan yang dilakukan pada level pembeli. Jumlah permintaan pada minggu pertama adalah sebanyak 480 unit. Jumlah barang yang dipesan oleh penjual dengan menggunakan metode Silver Meal adalah sebanyak 735 unit.

Tabel 4. Contoh Perhitungan Lot For Lot pada Level Penjual

\begin{tabular}{|c|c|c|c|c|c|c|c|}
\hline \multicolumn{7}{|c|}{ Wholesaler } \\
\hline Cinggu Ke & Demand & Q & Inrentory & Demand-Inrentory & A & Holding Cost & Iotal Cost \\
\hline 0 & & & 0 & & & & \\
\hline 1 & 480 & 480 & 0 & 480 & 400 & 0 & 400 \\
\hline 2 & 0 & 0 & 0 & 0 & 0 & 0 & 0 \\
\hline 3 & 439 & 439 & 0 & 439 & 400 & 0 & 400 \\
\hline 4 & 0 & 0 & 0 & 0 & 0 & 0 & 0 \\
\hline 5 & 432 & 432 & 0 & 432 & 400 & 0 & 400 \\
\hline
\end{tabular}

Tabel 4 merupakan hasil perhitungan metode Lot For Lot pada level penjual. Jumlah permintaan diperoleh dari jumlah pemesanan yang dilakukan pada level pembeli. Jumlah permintaan pada minggu pertama adalah sebanayk 480 unit. Jumlah barang yang dipesan oleh penjual dengan menggunakan metode Lot For Lot sama dengan jumlah permintaan, yaitu sebanyak 480 unit.

\section{Hasil dan Diskusi}

Verifikasi simulasi ini dilakukan dengan mengubah nilai standar deviasi permintaan. Standar deviasi permintaan diubah menjadi nilai yang lebih besar dan nilai yang lebih kecil daripada standar deviasi awal. Proses verifikasi ini hanya direplikasi sebanyak sepuluh kali dan diperoleh nilai rata-rata yang dapat dilihat pada Tabel 5 .

Tabel 5 menunjukkan hasil verifikasi yang diperoleh dengan melihat perubahan biaya per unit untuk setiap standar deviasi. Hasil ini menunjukkan bahwa simulasi yang dilakukan sudah benar. Hal ini terlihat dari semakin besar nilai standar deviasi dari permintaan, semakin tinggi pula cost per unit. Jadi, dapat dikatakan bahwa simulasi telah terverifikasi.

Perbandingan antar metode dilakukan dengan membandingkan rata-rata dan standar deviasi dari jumlah barang yang dipesan pada level pembeli dan penjual. Perbandingan juga dilakukan dengan membandingkan biaya per unit dari masing-masing metode yang digunakan. Hasil perbandingan rata-rata kuantitas pemesanan antar metode dapat dilihat pada Gambar 3.

Gambar 3 menunjukkan grafik perbandingan kuantitas pemesanan pembeli dan penjual untuk masing-masing metode. Hasil menunjukkan bahwa pada tingkat pembeli dan penjual memiliki rata-rata permintaan yang hamper sama namun berbeda halnya pada metode Lot For Lot-Silver Meal. Dimana ratarata permintaan pada metode Lot For Lot dan Silver Meal terlihat perbedaan yang tinggi antara tingkat pembeli dan penjual. Perbedaan ini menunjukkan adanya Bullwhip Effect. Hal ini dikarenakan pada tingkat pembeli yang menggunakan metode Lot For Lot, nilai pemesanan hampir mewakili nilai permintaan sebenarnya. Sedangkan pada tingkat

pembeli yang menggunakan metode Silver Meal, nilai permintaan sudah tidak sesuai dengan permintaan sebenarnya. Perbedaan variasi antara level pembeli dan penjual dapat dilihat pada Gambar 4.

\section{Rata-Rata Pemesanan}

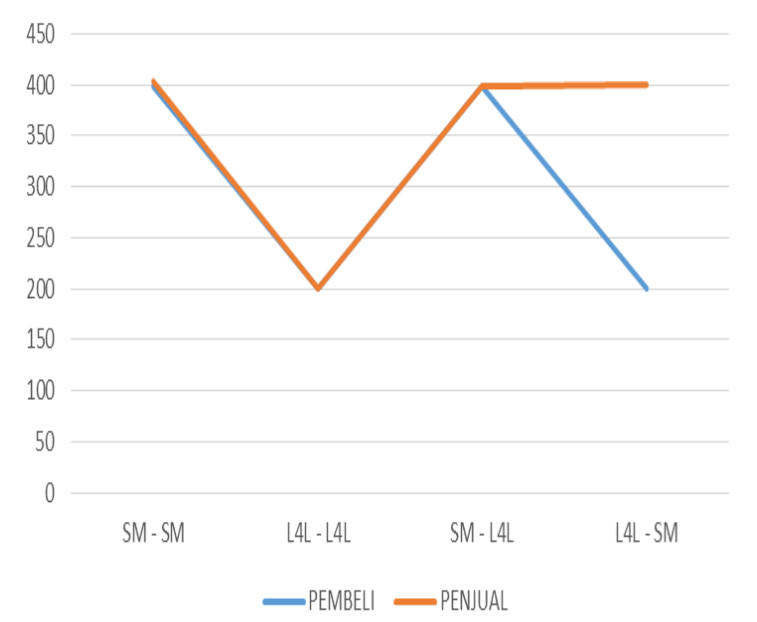

Gambar 3. Rata-Rata Kuantitas Pemesanan 


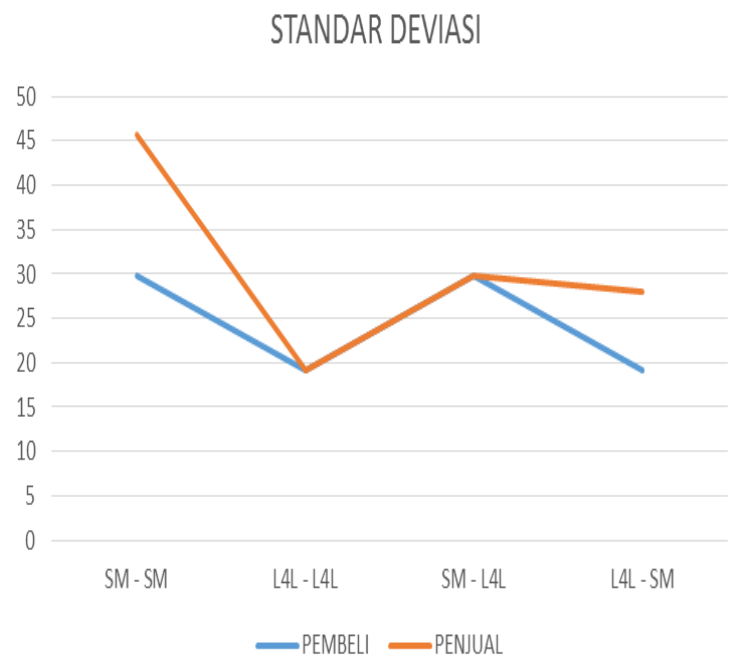

Gambar 4. Standar Deviasi Kuantitas Pemesanan

Tabel 5. Hasil Verifikasi

\begin{tabular}{|c|c|c|c|c|c|}
\hline & $\begin{array}{l}\text { Standar } \\
\text { Deviasi }\end{array}$ & $\begin{array}{c}\text { Silver } \\
\text { Meal } \\
\text { Silver } \\
\text { Meal }\end{array}$ & $\begin{array}{l}\text { Silver Meal } \\
\text { Lot For Lot }\end{array}$ & $\begin{array}{l}\text { Lot For Lot } \\
\text { Lot For Lot }\end{array}$ & $\begin{array}{l}\text { Lot For Lot } \\
\text { Silver Meal }\end{array}$ \\
\hline Standar Deviasi Kecil & 5 & 3.63 & 2.57 & 3.99 & 3.57 \\
\hline Standar Deviasi & 20 & 4.08 & 2.79 & 4.001 & 3.779 \\
\hline Standar Deviasi Besar & 60 & 4.71 & 2.87 & 4.007 & 3.97 \\
\hline
\end{tabular}

Gambar 5 menunjukkan standar deviasi dari kuantitas pemesanan yang diperoleh dari masing-masing metode yang digunakan. Hasil ini menunjukkan bahwa variasi permintaan terendah pada level pembeli adalah variasi yang diperoleh dengan menggunakan metode Lot For Lot. Hal ini dikarenakan metode Lot For Lot melakukan pemesanan sesuai dengan jumlah permintaan sehingga variasi pemesanannya juga hampir sama dengan variasi permintaan. Metode Silver Meal pada level pembeli memiliki variasi yang lebih besar karena perhitungan jumlah pemesanan memperhitungkan adanya safety stock sehingga variasi pemesanan akan lebih besar daripada variasi permintaannya. Gambar 5 juga menunjukkan bahwa variasi jumlah pemesanan di level penjual dengan metode Silver Meal paling tinggi jika dibandingkan dengan metode lain. Hal ini dikarenakan variasi pemesanan sudah tidak sesuai dengan permintaan yang sebenarnya.

Gambar 5 menunjukkan perbandingan biaya per unit dari masing-masing metode. Biaya per unit pada level pembeli yang lebih rendah adalah dengan menggunakan metode Silver Meal. Penggunaan metode Silver Meal akan memperkecil jumlah pemesanan selama dua periode sehingga biaya pemesanan akan lebih kecil jika dibandingkan dengan metode Lot For Lot.

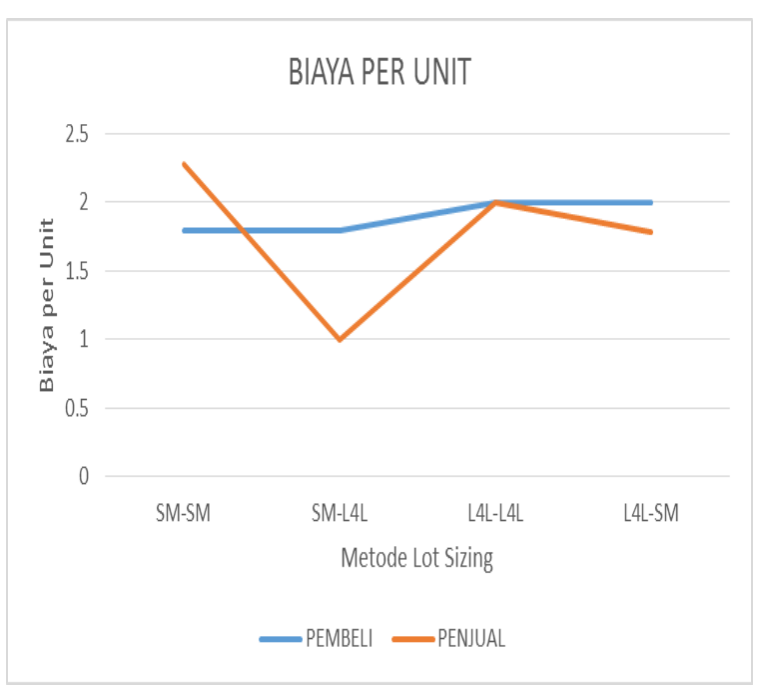

Gambar 5. Biaya per Unit

Biaya per unit yang terendah pada level penjual adalah dengan menggunakan metode Lot For Lot dimana pada level pembeli, penentuan kuantitas pemesanan dilakukan dengan menggunakan metode Silver Meal. Hasil dari biaya per unit ini juga dapat dihubungkan dengan rata-rata permintaan dan variasi permintaan dari setiap kombinasi metode. Dimana 
kombinasi metode Silver Meal dan Lot For Lot memiliki rata-rata permintaan dan variasi permintaan yang sama dan memiliki biaya per unit terendah. Kombinasi metode Silver Meal dan Silver Meal, Lot For Lot dan Lot For Lot juga memiliki rata-rata permintaan dan variasi permintaan yang sama namun memiliki biaya yang lebih tinggi. Kombinasi metode Lot For Lot dan Silver Meal dan kombinasi Silver Meal dan Silver Meal tidak dapat digunakan karena kombinasi metode tersebut dapat menimbulkan Bullwhip Effect pada variasi permintaannya.

Perbandingan antar metode dilakukan dengan membandingkan biaya per unit yang diperoleh dengan menggunakan metode Lot For Lot, metode Silver Meal, dan kombinasinya. Perbandingan juga dilakukan dengan melihat hubungan standar deviasi permintaan dengan biaya per unit yang diperoleh. Nilai rata-rata per unit diperoleh dari hasil pembagian total biaya dengan total permintaan. Rata-rata biaya per unit yang diperoleh dari metode Silver Meal pada pihak pembeli adalah sebesar 1.79. Rata-rata biaya per unit pada pihak penjual adalah sebesar 2.27. Total biaya per unit dari metode Silver Meal ini adalah sebesar 4.06 .

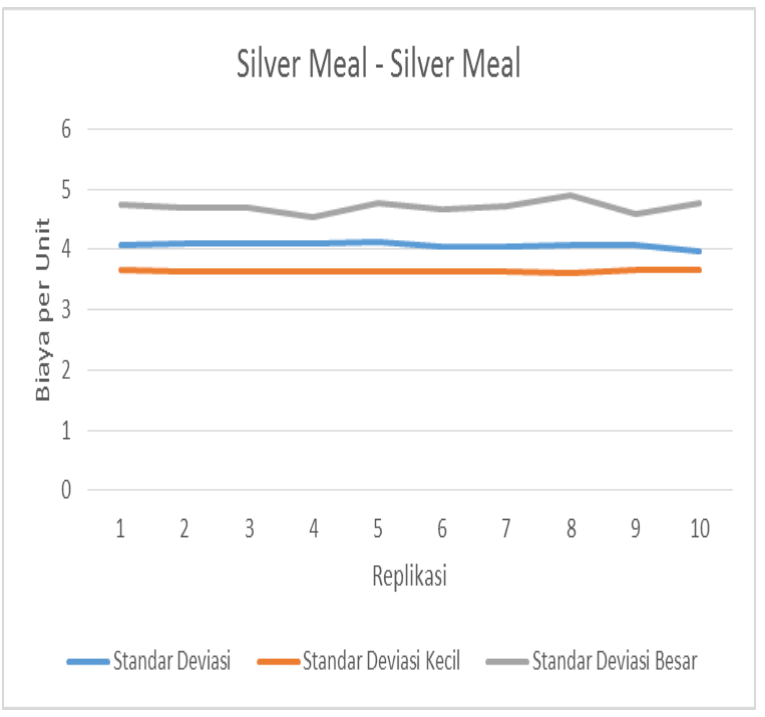

Gambar 6. Hasil Perhitungan Silver Meal - Silver Meal

Gambar 6 menunjukkan grafik perbandingan biaya per unit untuk setiap standar deviasi dengan menggunakan metode Silver Meal pada level pembeli dan penjual. Standar deviasi yang digunakan adalah 5, 20, dan 60. Gambar 6 membuktikan bahwa semakin besar standar deviasi maka akan semakin besar juga biaya per unitnya.

Penentuan jumlah pemesanan juga dilakukan dengan menggunakan kombinasi Silver Meal -Lot For Lot. Biaya per unit dari penerapan metode Silver Meal pada pihak pembeli dalam rantai pasok adalah sebesar 1.79. Metode Lot For Lot yang diterapkan pada penjual memiliki nilai biaya per unit sebesar 1 sehingga diperoleh total biaya per unit dari kombinasi ini sebesar 2.79.

Gambar 7 menunjukkan grafik perbandingan biaya per unit untuk setiap standar deviasi dengan menggunakan metode Silver Meal pada pembeli dan metode Lot For Lot pada penjual. Standar deviasi yang digunakan adalah 5, 20, dan 60. Gambar 7 juga membuktikan bahwa secara umum semakin besar standar deviasi permintaan maka semakin besar biaya per unit.

Biaya per unit yang diperoleh dari metode Lot For Lot pada pihak pembeli dalam rantai pasok adalah sebesar 2. Perhitungan selanjutnya dilakukan untuk pihak pembeli dimana jumlah permintaannya sama dengan jumlah pemesanan dari pembeli. Hal ini menyebabkan biaya per unit yang diperoleh juga sama, yaitu sebesar 2. Total biaya per unit dari metode ini adalah sebesar 4 .

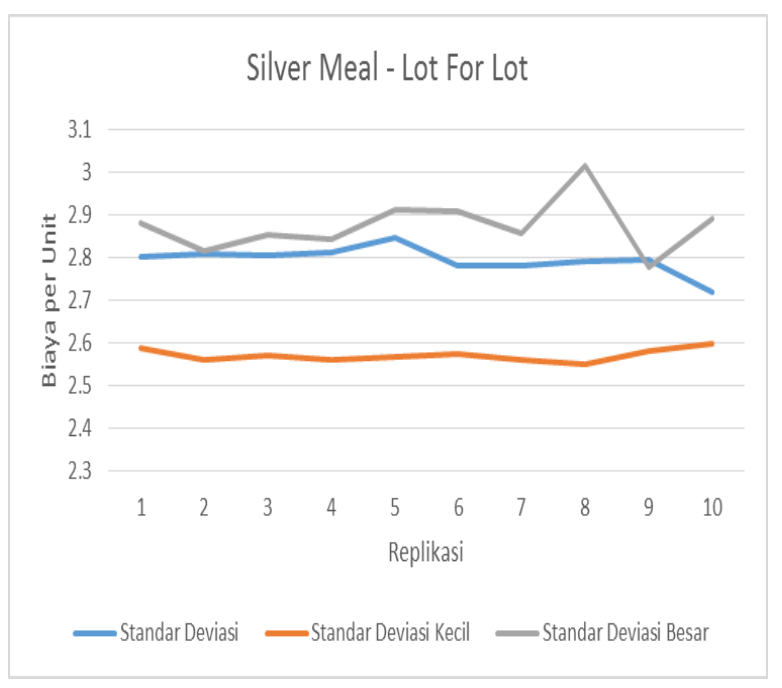

Gambar 7. Hasil Perhitungan Silver Meal - Lot For Lot 


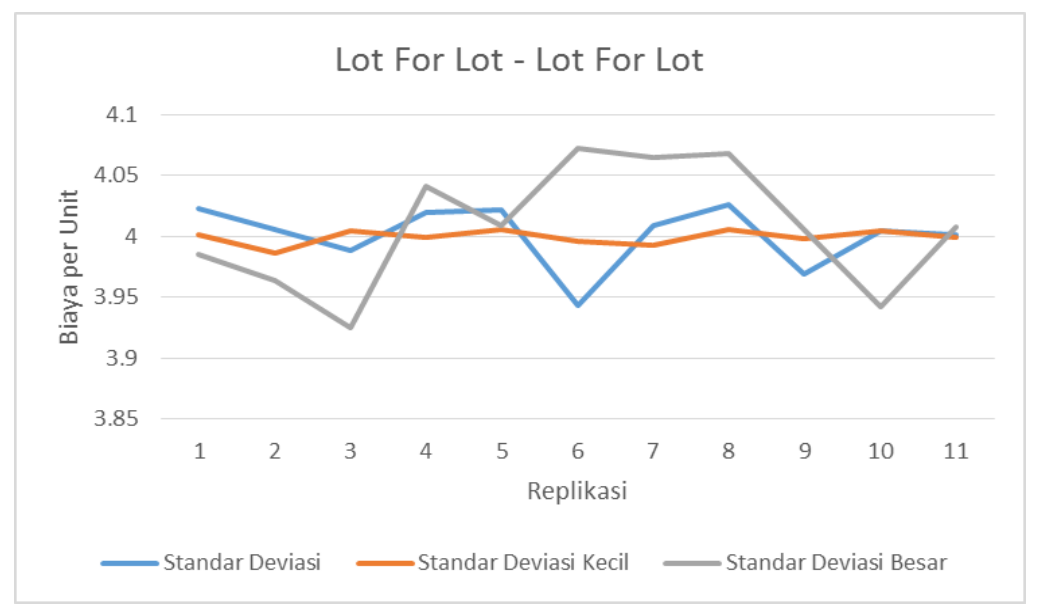

Gambar 8. Hasil Perhitungan Lot For Lot - Lot For Lot

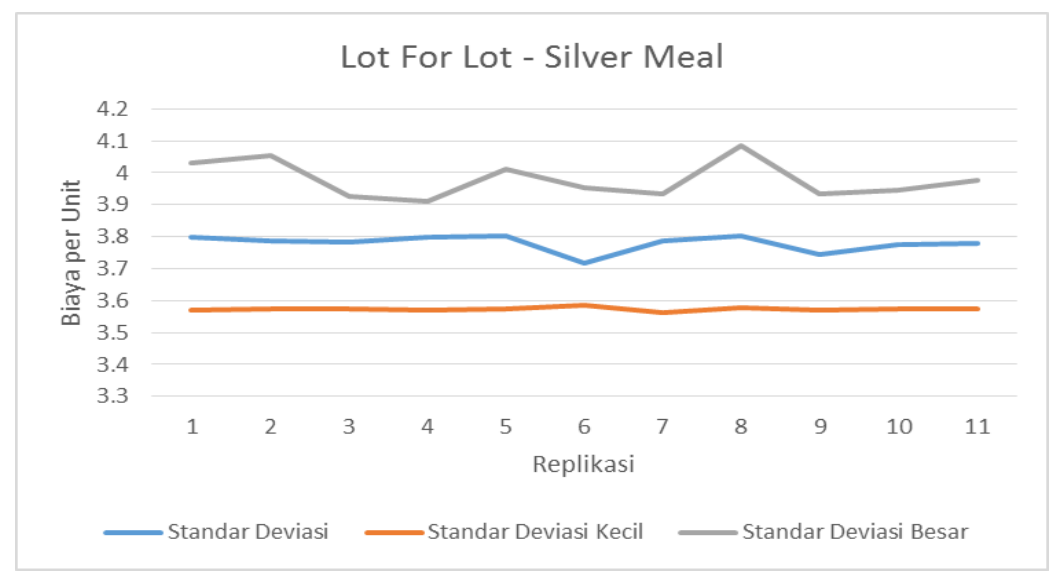

Gambar 9. Hasil Perhitungan Lot For Lot-Silver Meal

Gambar 8 menunjukkan grafik perbandingan total biaya per unit dengan metode Lot For Lot - Lot For Lot untuk setiap standar deviasi. Standar deviasi yang digunakan adalah 5, 20, dan 60. Gambar 8 membuktikan bahwa metode Lot For Lot tidak dipengaruhi oleh perubahan standar deviasi. Hal ini dikarenakan karakteristik dari metode Lot For Lot yang tidak memperhitungkan standar deviasi dalam menentukan jumlah pemesanan.

Perhitungan selanjutnya dilakukan untuk mengetahui biaya per unit dari kombinasi Lot For Lot - Silver Meal. Biaya per unit yang diperoleh dengan menggunakan metode Lot For Lot pada pihak pembeli adalah sebesar 2. Biaya per unit yang diperoleh dengan menggunakan metode Silver Meal pada pihak penjual adalah sebesar 1.78. Jadi, total biaya per unit dari kombinasi metode Lot For Lot Silver Meal adalah sebesar 3.78.

Gambar 9 menunjukkan grafik perbandingan total biaya per unit untuk metode Lot For Lot pada pembeli dan metode Silver Meal pada penjual terhadap nilai standar deviasi yang berbeda. Standar deviasi yang digunakan adalah 5, 20, dan 60. Hasil menunjukkan bahwa pada perubahan standar deviasi berbanding lurus dengan total biaya per unit.

Hasil penelitian ini menunjukkan bahwa penentuan jumlah pemesanan akan sangat mempengaruhi total biaya per unit pada rantai pasok. Pada kondisi nyata, setiap pemasok tidak mempertimbangkan jumlah pemesanan secara pasti karena berasumsi pemenuhan permintaan konsumen berarti meminimalkan biaya. Namun, hasil penelitian ini menujukkan bahwa jumlah pemesanan sangat mempengaruhi biaya yang dikeluarkan. Hasil penelitian ini menunjukkan bahwa pada pihak pembeli lebih baik menggunakan metode Silver Meal. Hal ini dikarenakan variasi permintaan masih stabil dan mewakili permintaan nyata. Penggunaan metode Silver Meal akan memperkecil jumlah pemesanan selama dua periode sehingga biaya pemesanan akan lebih kecil jika dibandingkan dengan metode Lot For Lot. Variasi pemesanan pada level pembeli sudah tidak dapat mewakili kondisi nyata karena jumlah pemesanan tersebut telah dipengaruhi oleh jumlah barang yang akan disimpan sebagai safety stock. 


\section{Kesimpulan}

Penelitian dilakukan dengan membandingkan metode Silver Meal dan metode Lot For Lot terhadap bullwhip effect yang terjadi pada pembeli dan penjual dalam rantai pasok. Perbandingan dilakukan dengan melihat biaya per unit dari masing-masing metode serta kombinasinya. Hasil yang diperoleh menunjukkan bahwa metode yang lebih baik digunakan adalah kombinasi Silver Meal - Lot For Lot, dimana pembeli lebih baik menggunakan metode Silver Meal sedangkan penjual lebih baik menggunakan metode Lot For Lot. Kombinasi ini dipilih agar dapat mengurangi pengaruh Bullwhip effect dimana rata-rata permintaan dan variasi permintaan kombinasi metode ini memiliki nilai yang hampir sama dan tidak terjadi perubahan dari pembeli ke penjual. Walaupun kombinasi metode lain juga memiliki nilai rata-rata dan variasi yang sama, namun kombinasi metode Silver Meal dan Lot For Lot (pembeli dan penjual) ini menghasilkan biaya per unit yang lebih murah. Kombinasi metode ini menghasilkan biaya per unit yang terendah karena pada pembeli, jumlah barang yang dipesan untuk setiap pemesanan digunakan untuk memenuhi permintaan selama beberapa periode.
Hal ini didukung oleh variasi permintaan pada level pembeli yang masih stabil dan dapat mewakili permintaan sesungguhnya, sedangkan variasi permintaan pada penjual sudah mempertimbangkan jumlah safety stock.

\section{Daftar Pustaka}

Lee. (1997). Bullwhip Effect in Supply Chains. In L. a. Al, Sloan Management Review (p. 93).

Parwati, I. (2009). METODE SUPPLY CHAIN MANAGEMENT. Jurnal Teknologi Vol 2 No. $1,47-52$.

Heizer, J., \& Render, B. (1996). Production and Operations Management. Prentice Hall.

Gaspersz, V. (2004). Production Planning and Inventory Control. Jakarta: PT Gramedia Pustaka Umum.

Pujawan, I. N. (2003). The effect of lot sizing rules on order variability. European Journal of Operational Research, 3.

Simchi-Levi, D., Kaminsky, P., \& Simchi-Levi, E. (2003). Designing and Managing The Supply Chain: Concepts, Strategies, and Case Studis. Singapore: McGraw-Hill. 